State of Alaska

inpartment of Natural Resources

VISION OF MUNES AND MUNERALS
PROPERTY OF

LIBRARY

STATE OF ALASKA

DIVISION OF

GEOLOGICAL SURVEY

$\therefore$

MINES AND PETROLEUM BULJETIN

January, 1963
P. 0. $80 \times 1391$

Juneau, Alanka-
Vol. XI

No. 1

\title{
MINTIG ACTIVITIES
}

Northwestern Distrlct: $=$ Word has been received that the U. S. Smelting, Refining and Minling Company has prepared a shelf and has stored Number 5 dredge on it for an indefinlte. period. Number 6 was also shelved this season.

Southeastern District - Limestone from Alaska mut be becoming competitive vith limestone from other states in the Puget Sound area fudging by the increase in number of clatms staked in thel Panhandle and the number of letterg requesting information on Ifmestone deposits available for claiming recelved by the Juneau office of the DMom.

Central Diatrict - L. and Helen MoGee have optioned several claims on Cache Creek in the Manley areai and heve been arililing act1vely. They also moved some heavy equipment on the ground and started trenching. The claims are on ground previously drift mined.

Ed Farrell and a partner are expected to start drilling Big Boulder Exeek next. aimmer, and Louls Holöiscs, Jr. Is preparing to sluice on American Creek.

\section{OII NEWWS}

Four permits to drill have been approved by the Petroleum Branch since the date of the last Bulletin. They are a follows: (1) Richfield Oil Company Wide Bey HI, 560' S. and $800^{\prime}$ E. of NW corner, Sec. 5, 335-44W. S.M. This well is being drilled from a stationary plifing platform in Wide Bay, connected to the mainland by a couseway; (2) Sinclair 0il \& Gas Compary 'Hystery Creek \#I, (Swan Lake Unit) 660 N.C., 1980' El., Sec. 3, T. TN-R.6W. . S.M.; (3) Standard Oll Co. of California, B.R.U. 232-4, $1990^{\prime}$ from N. Ine, $1987^{\prime}$, from E: line, Sec. 4, I2N.-IOW. B.M. This location is over a mile south of the Beluga River gas discovery; (4) Standara 011 ' $\mathrm{CO}$ : of Californié, S.C.U. $22 \mathrm{~A}-32 \mathrm{RD}, 2115^{\prime} \mathrm{S}$. and $2080^{\prime} \mathrm{E}$. from NW corner, Sec. 32, TN-9W. S.M. This location is a redrili of S.C.U. 22-32 lying about 3 infles north of fleld production and is expected to reech a depth below 14,000'. The new bottom hole, location will lie approximately $700^{\circ} \mathrm{N} .45^{\circ} \mathrm{E}$. of the surface location.

\section{Drilling Activity}

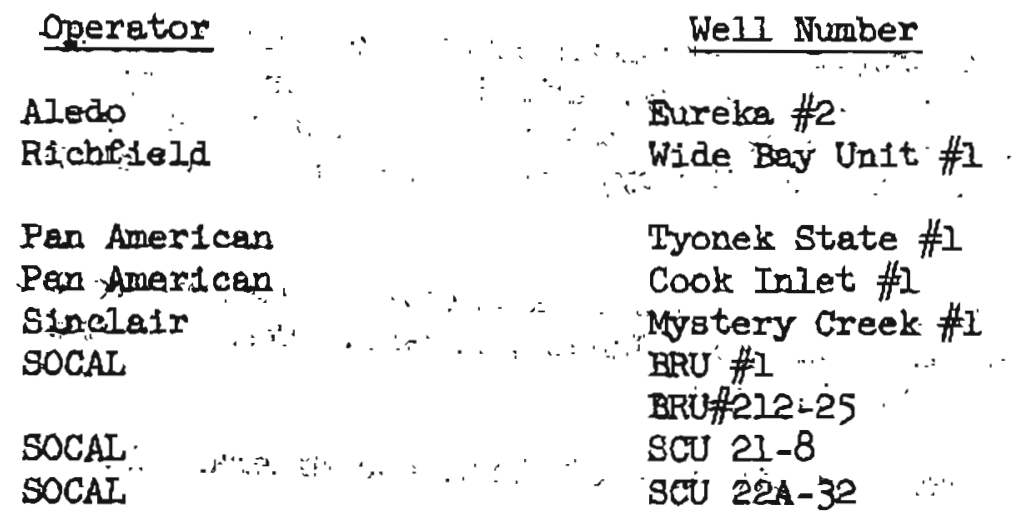

Stetus $12 / 27 / 62$

Dris. 6,024 !

Runiting. conductor pipe '. TDO 37.5 !

Fishing at 13,067 '

Burning ID 12,000'

Moving in

Testing TI 16,4281

Testing ID $, .5,800^{\prime}$

Dris. 4293'

Preparing, to mill for redrili 
Drilling Activity (cont.)

\section{Operator}

SOCAL

SOCAI,

SOCAI'.
Well Number

SGŨ : 43-9

SRU $14-9$

SRU 14-22
Status $12 / 27 / 62$

Location

Drlg. 12,518'

Drig. 6,390'

Completions and Abandonments

Pan American

SOCAL

Union
Cook Inlet $1-A$

Anchor Point

Ninilchik \#1
Suspended TD 11,549'

P\&A TD $14,705^{\circ}$

P\&A TD $14,940^{\circ}$

Production Swanson River Field, Hemlock Zone

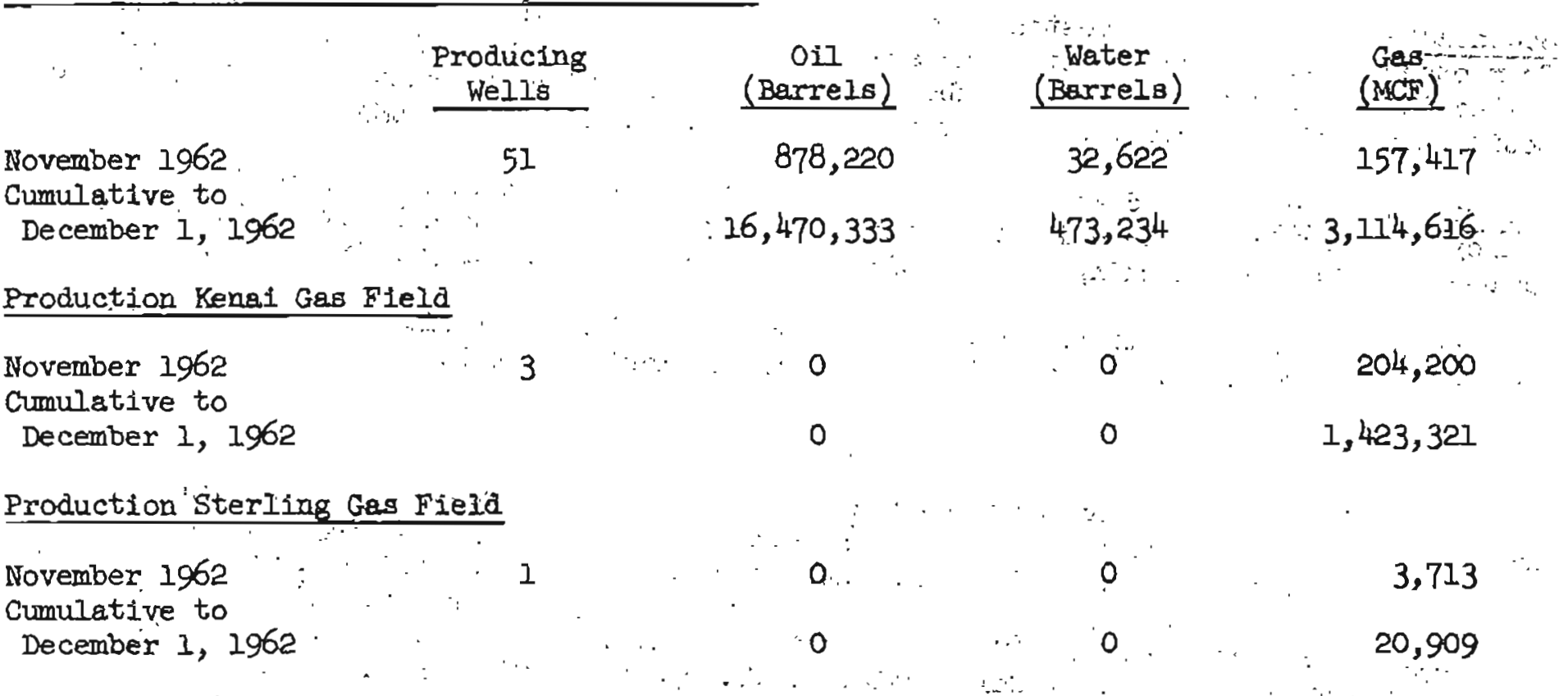

The daily rate of oil and gas production were at new highs during the month of November.

In the Swanson River Field, the gais repressuring project was started by the converaion of one oil well, SCU 12-9 to gas injection. A totial of 32,710 MCF was injected into. this well during the month. Four adjitional gas injection wells are planned. These are to be converted for injection in the near future.

Safety Regulations tearing - The adoption of proposed Petroleum Safety Regulations, pertaining to health and safety in all oil and ges exploratory, drilling, and producing operatlons within the State of Aleska, will be discussed at a public hearing to be held at 9:30 A.M., January 30, 1963, in the Z. J. Loussac Library, 5th Avenue and F street in Anchorage.

Any person interested may appear and be heard, or may submit a written statement to the Director of the Division of Mines and Minerals, Box 1391, Juneau, Alaska. Comments are solicited from both workers and companies in the industry.

Coples of the reguiations are available from the Division of Mines and Minerals in Juneeu and Anchorgige. 
Tevelopment"Contracts Terminated - As of December 6, 1962, Richfield oil Company termiiated the Katalla-Yakataga Development Contracts \#3 and \#2 lying on the north centrai coast of the Gulf of Alaska. Richfiela has drilled 6 wells in the general area.

Lease Sale Cancelled - The State of Aleska, Division of Lands, has cancelled the tenth Competitive 0il and Gas Lease Sale, scheduled for January 31, 1963. This action was determined to be in the best interest of the state because of the unavailability of acreage nominated within and on the exterior boundaries of the Susitna Gunnery Range. Commissioner of the Department of Natural. Resources, Phil Holdsworth, has been absured by Bureau of Land Management officials that the acreage concerned would be tentatively approved and therefore available for leasing by the spring of 1963.

Weather Forces Pan American Petroleum to Abandon Relief Well Attempt - The pressure of Ice floes on Pen American offshore rig drilling Cook Inlet 1-A, broke two of the anchor cables and swept a tender away from the drilling barge. The hole was filled with heavy drilling mud and sealed at the ocean floor so that it cain be re-entered in the spring. The well is now suspended at a total depth of $21,549 \%^{\circ}$ within approxingitely 750 ' of the programmed depth where an intersection with the bore hole of the burning well was expected. An informal meeting was beld Friday, November 30, by request of Governor Egan to announce to the public that the State had approved the suspension of this well and to obtain views of interested parties. Comissioner of the Department of Natural Resources, Phil Eoldsworth, conducted the meeting in Anchorage.

Standard Oil Company Announces Gas Discovery - A press release deted December 3, 1962, announced that SOCAL had tested- the Beluga River Unit \#l through casing at approximately 4,800'. The well. flowed methane gas at the rate of 4,300,000 cublc feet of gas per day hrough a $1 / 4 "$ choke. This. new'fleld lies near the moutb of the Beluga River on the west side of Upper Cook Inlet. SOCAL is:now orilling another well in this unit about $11 / 4$ miles north of the discovery."

\section{MTNERAI PRODUCTION 1962}

Preliminary production figures prepared by the U. S. Bureau of Mines under a cooper-. ative agreement for the collection of mineral date with the Division of Mines and Mirierals were released December 28. Mr. Kevin Malone, Physical Scientist, Alaska Office of Mineral Resources, U. S. Bureau of Mines is to be comended upon the early publication of these preliminary figuress.

The following excerpts are quoted directly.

Value of 1962 :mineral production in Alaska increased 36 percent compared with that of: 1961 , according to estimates of production compiled by the Bureal of Mines, $U$. $S$. Department of the Interior. Crude oil from the Swanson River flela on the Kenal Peninsula, reflecting a full year of production at the operating capacity of the swanson-Nikiski pipeline, was aga the leading mineral comodity lncreasing 59 percent in value. Despite an increase of 40 percent in value of gold, coal retained second rank; gold repleced sand and gravel as the third ranking mineral comodity. 
Preliminary estimate, minerel production in Alaska, 1962

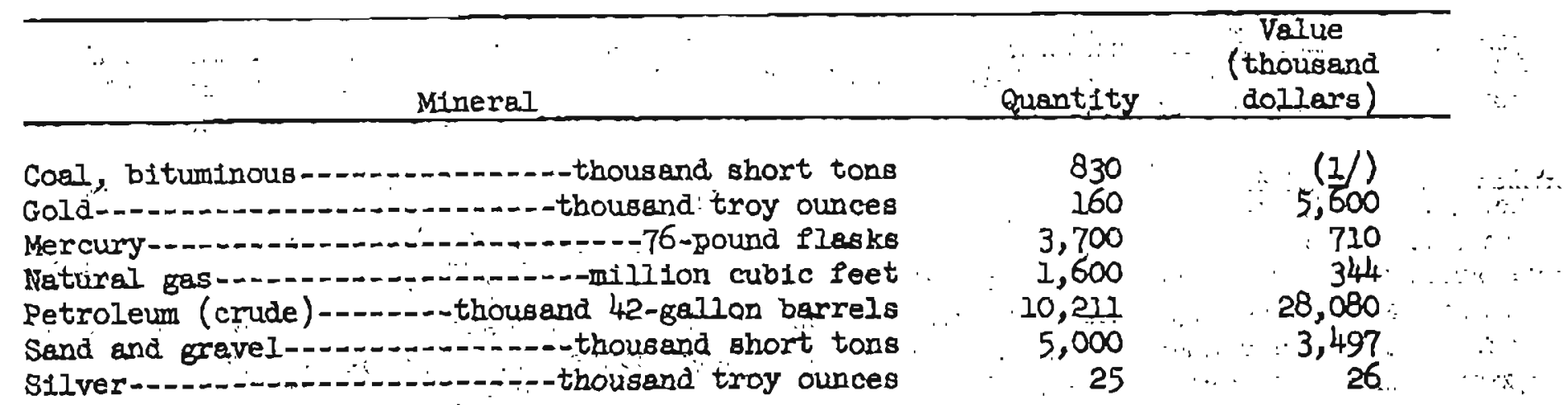

Value of items that cannot be disclosed:

Coal, copper, gem stones, platinum-group

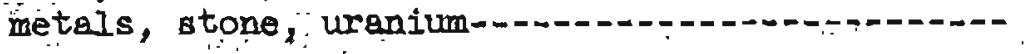

Alaska total

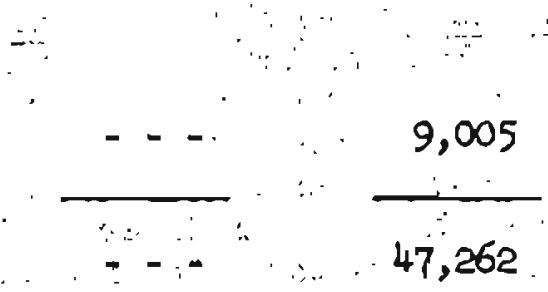

if Included with value of itoms that cannot be disclosed.

DEPARTMENT OF TNIERIOR ANNOUNCES JOINI SPONSORSEIP. OF INATIONAL SAFETY COMPETITION

The American Mining Congress hes joined the Bureau of Mines in Bponsoring the 37-yearold Nationel Safety Competition, whloh: has been a potent force in promoting accident prevention in the mineral industries of the United States.

The competition was co-sponsored by the Bureals of Mines and "The Explosives Fingtneer" from 1925 until 1961, when that magarine ceased publication. This year's contest had 868 participants, and was sponsored by the Bureau of Mines alone.

\section{YUKON PERRITORY IRON}

The Western Miner \& 011 Review reporț that a feesibility study is being conducted by Canadian Bechtel Ltd., on behalf of Crest Exploration Ltd., orners of the vest hematite deposit on the Snake River, a tributary of the Peel River. Bechtel w1ll devote much of 1 ts time to planning the route and estimating cost of a raflroed to.tide-water near Skagway or Haines.

\section{CANADIAN LIMESTONE}

The Mining Congress Journel reports that 400,000 to 500,000 tons of Ilmestone will be imparted annualiy by Oregon Portland Cement Compeny over the next ten yeara for lise at Its oswego, Oregon cement plant.: The first shlpnent to the plant was recently recelved from Texade Íland, British Colimbia, aboard the cargo barge, Island Bcporter. It is... one of two barges that will transport limestone to Oswego to assure weekly deliverles of 10,000 tons. A company-owned quarry at Lime, Oregon had previously supplled the plant. The ewitch to Canadian limestone was said to result in considerable frelght savings. 


\section{P. L. 167 AREAS FOR DEIERMROATION OF SURFACE RIGHTS}

Another area has been designated by the U. S. Forest service for the determination of urface rights on mining claims under Public Law 167 of July 23, 1955. This is in addition to many earlier areas within the Tongass and Chugach National Forests, all reported in earlier DMRM Bulletins. Holders of claims staked prior to the date of the Act have 150 days from the starting date of publication to file verified statements if they wish to retain exclusive surface rights to their claims. First publication is to be on January 4, 1963, in the Petersburg Press.

Hamilton Bay Area (Anchorage 057928). In general, exclusive of Kake elimination, all lands draining into Hamilton Bay and Big John Bey.

\section{NORTHWEST MLNERS ASSOCIATION}

Q. K. Barnes, president of the Northwest Miners Association, forecast contimuing depletion of the nation's gold reserves in his opening address to the Association's 68th anmul convention in Spoksne. He said, "reveluation of gold in terms of the world's depreclated currencies is inevitable because the U. S. Treasury is runing out of gold Just as surely as it ran out of free silver last year." He stated that the United States wll continue to lose gold as long as forelgn countries can buy it at a 1934 bargain price of $\$ 35$ an ounce. Barnes noted that since the Government had removed its restrictions on the sale of silver, the price of the metal had increased nearly 50 percent and was approaching ita true value.

\section{PUBLIC BEARINGS ON STREAM FERMITS}

The Alagka Department of Fish and Game has announced that public hearings will be held .n Anchorege on January 16 at 7:30 P.M., at the Loussac Library and in Fairbenks on Jenuary 18 at 8 P.M., at the Chamber of Comerce Buflding.

A list of waters subject to permits has been complied from recomendations submitted to the Department. The list is tentative and is subject to addition or deletion as may be necessary.

Chapter 132, SIA 1962, provides that the Combsioner of Fish and Game must be notified prior to use of those streems designate $\bar{a}$ by the Comissioner as important for the spawning or migration of anedromous izsh. Chepter I32 also provides that the Comissioner's designation of streams shall be made in accordance with the Administrative Procedures Act.

E. AND M. J. MELAI MARKET PRICES

$$
\text { Dec. 31, } 1962
$$

Copper, per $2 \mathrm{~b}$.

Lead, per $1 b$.

Zinc, per lb.

Tin, per $1 b$.

Nickel, per $1 b$.

Platinum, per oz.

Mercury, per flasik

Antimony ore, per unit

Beryllium ore, per unit

Chrome ore, per long ton

Molybdenum conc., per $1 b$.

Titanium ore, per ton

Tungsten ore, per unit

Silver, foreign, per oz.

Silver, domestic, per oz.

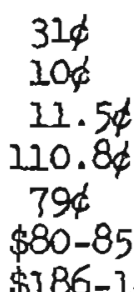

$\$ 186-189$

$\$ 4.25-4.50$

Domestic price not quoted.

$\$ 36-38$

$\$ 3.40$

$\$ 23-26$

$\$ 16-20$

120.334

90.54

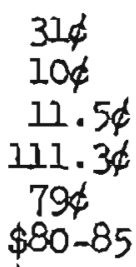

$\$ 190-193$

$\$ 4.25-4.50$

$\$ 36-38$

$\$ 1.40$

$\$ 23-26$

$\$ 16-20$

118.354

90.54
Year Ago

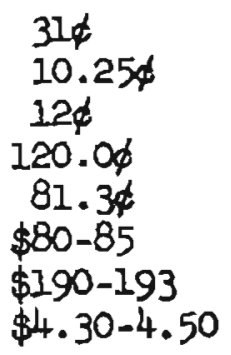

$\$ 36-38$

$\$ 1.40$

$\$ 23-26$

$\$ 20-22$

91.44

90.54 


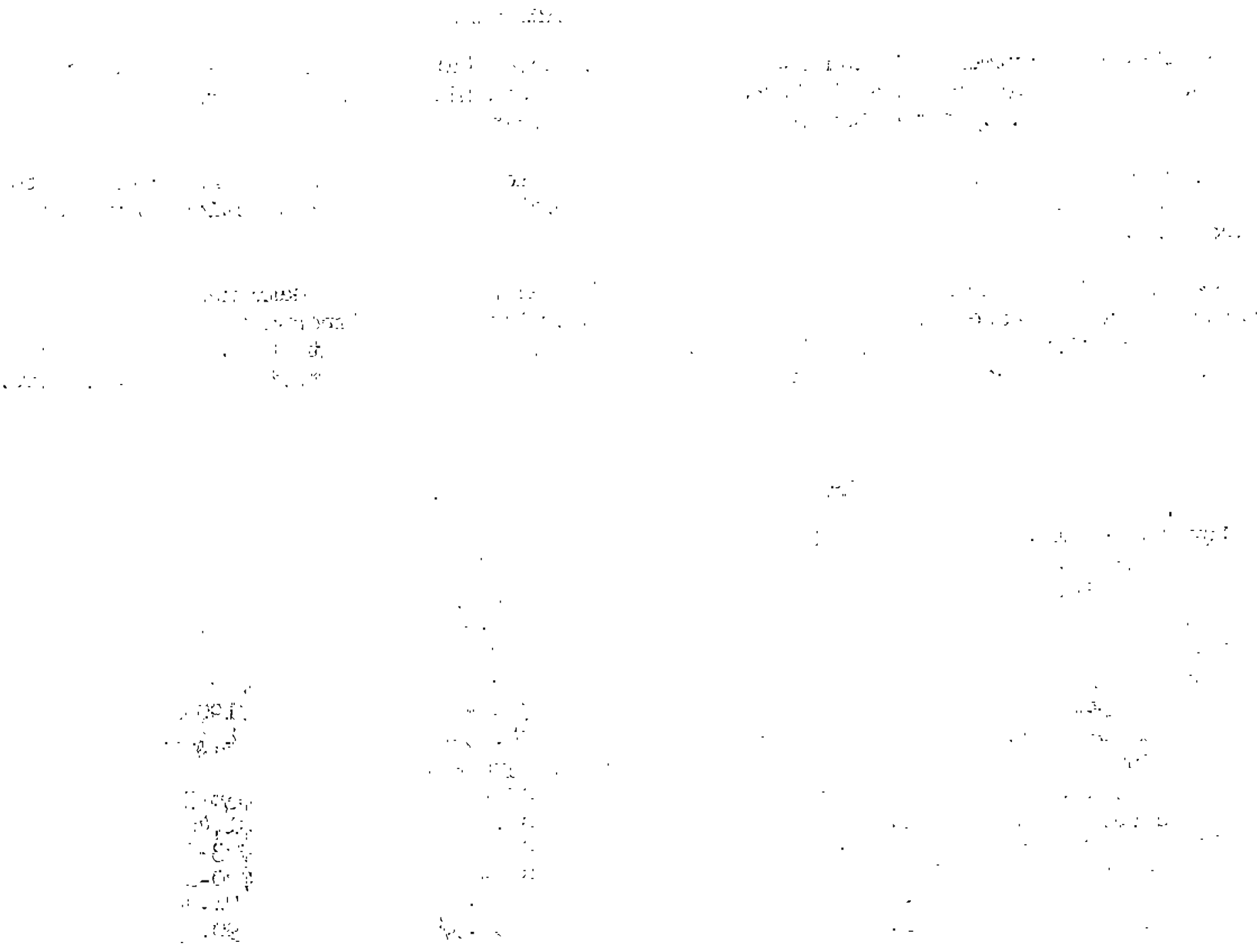

